\title{
Resolution of taxonomic problems in Australian Harpalini, Abacetini, Pterostichini, and Oodini (Coleoptera, Carabidae)
}

\author{
Kipling Will' \\ I Essig Museum of Entomology, University of California, Berkeley, CA, USA \\ Corresponding author: Kipling Will (kipwill@berkeley.edu) \\ Academic editor: L. Penev | Received 5 October 2015 | Accepted 13 November 2015 | Published 14 December 2015 \\ http://zoobank.org/3376A343-C4E4-4660-B9D3-07B7113FF93E \\ Citation: Will K (2015) Resolution of taxonomic problems in Australian Harpalini, Abacetini, Pterostichini, and Oodini \\ (Coleoptera, Carabidae). ZooKeys 545: 131-137. doi: 10.3897/zookeys.545.6752
}

\begin{abstract}
Taxonomic changes are made for several problematic Australian Carabidae in the tribes Harpalini, Abacetini, Pterostichini, and Oodini. Examination of types resulted in the synonymy of Veradia Castelnau, 1867 with Leconomerus Chaudoir, 1850; Nelidus Chaudoir, 1878, Feronista Moore, 1965, and Australomasoreus Baehr, 2007 with Cerabilia Castelnau, 1867; and newly combining Fouquetius variabilis Straneo, 1960 in the genus Pediomorphus Chaudoir, 1878; Australomasoreus monteithi Baehr, 2007 in the genus Cerabilia Castelnau, 1867; and Anatrichis lilliputana W.J. Macleay, 1888 in the genus Nanodiodes Bousquet, 1996. Cuneipectus Sloane, 1907 is placed in Pterostichini Bonelli, 1810, which is a senior synonym of Cuneipectini Sloane, 1907.
\end{abstract}

\section{Keywords}

Ground beetles, classification, Australia, New Zealand

\section{Introduction}

In a continuing effort to make the faunal list of Australian carabid beetles as accurate as possible, I sought out and studied type specimens for a number of historically problematic taxa. Results of my study require a number of adjustments to recognized taxa. 


\section{Methods}

Institution codens used here for material examined: Australian National Insect Collection (ANIC) CSIRO, Canberra; Essig Museum of Entomology (EMEC), Berkeley; Museo Civico di Storia Naturale "Giacomo Doria" (MCSN), Genova; Muséum National d'Histoire Naturelle, (MNHN), Paris; Museum of Comparative Zoology (MCZ), Harvard; Naturhistorisches Museum Basel (NMB), Switzerland; Queensland Museum (QM), Brisbane; and Western Australian Museum (WAM), Perth.

\section{Results and Discussion}

\section{Harpalini Bonelli, 1810}

Lecanomerus Chaudoir, 1850; type species, Lecanomerus insidiosus Chaudoir, 1850.

= Veradia Castelnau, F.L. Laporte de, 1867; type species Veradia brisbanensis Castelnau, F.L. Laporte de, 1867. syn. n.

Lecanomerus brisbanensis (Castelnau, 1867). comb. $\mathbf{n}$.

Material examined. Holotype, male [MCSN]. Type locality Brisbane. A female specimen, "26.49S 151.58E [29 49'S / 151 ${ }^{\circ} 58^{\prime} E$ ] Yarraman QLD State F. No. 282, 31 Mar. 1982, R.A. Barrett, M. Lenz, L. Miller"//"Rotten log" [ANIC].

Notes. Originally this species was placed by Castelnau (1867) near Moriodema Castelnau, 1867, a Moriomorphini taxon, which was then considered to be within Pterostichini. Subsequently it was moved to Harpalini by Chaudoir (1880) and according to Chaudoir it did not differ from Hypharpax W.S. Macleay, 1825. Sloane (1898) agreed with the placement in Harpalini, but deferred on the generic assignment and its possible similarity to Hypharpax. Straneo (1941) thoroughly reviewed the pertinent literature and studied the type specimen of Veradia brisbanensis. He concurred with the placement in Harpalini and suggested there were similarities with Nemaglossa Sloane, 1920 (=Lecanomerus Chaudoir, 1850, not Nemaglossa Solier, 1849), Euthenarus Bates, 1874 and Diaphoromerus Chaudoir, 1843 (= Notiobia (Anisotarsus) Chaudoir, 1843). These taxa fall in three different tribes of Harpalini and Straneo pointed out that without access to Australian material for comparison that he could not make a decision regarding the status or relationships of the genus and species. Moore et al. (1987) maintained the genus in Harpalitae incertae sedis, accurately reflecting the uncertainty of the placement of the taxon at that time.

I examined the holotype and confirm that it has typical Harpalini character states, e.g. single supraorbital seta and no elytral plica, and does not have any character states that would place it in any other tribe. Additionally the male has the front and middle tarsomeres expanded with spongy ventral pads, the penultimate labial palpomere is 
bisetose, the posterior lateromarginal seta of pronotum is absent and the angular base of stria 1 is absent. This combination of character states is consistent with placement of this taxon in subtribe Pelmatellina and is identical to the state combination found in many Australia Lecanomerus species. Based on this evidence, Veradia is considered a junior synonym of Lecanomerus.

A search in the holdings of the ANIC and QM did not yield any additional specimens of this species beyond the single female, but at least six very similar looking Lecanomerus species were found. Each was distinctly different, but all are very likely closely related based on their general similarity. How many of these are currently named species cannot be assessed without recourse to the types.

\section{Abacetini Chaudoir, 1873}

Pediomorphus variabilis (Straneo, 1960), comb. $\mathrm{n}$.

= Fouquetius variabilis Straneo, 1960

Material examined. Holotype, male [NMB]. Type locality Katherine, Northern Territory. Examined images only.

Notes. Straneo (1960) discusses at length his sense that Holconotus SchmidtGoebel, 1846 (= Fouquetius Maindron, 1906) and Pediomoprhus Chaudoir, 1878 are closely related and that Pediomorphus macleayi Sloane, 1900 could be a species of Holconotus. Moore (1965) confirmed that P. macleayi is a true Pediomorphus. Straneo's conclusions are based on very limited material and he did not discuss characters that allow for clear placement of species in these two genera. Among other characteristics, Pediomorphus has distinctly expanded penultimate labial palpomeres not found in Holconotus, while the elytral lateral bead is distinctly, finely serrate in Holconotus and smooth in Pediomorphus. The type specimen of Pediomorphus variabilis has clearly expanded penultimate labial palpomeres and smooth elytral lateral beads. Given the new combination, Holconotus is removed from the Australian faunal list.

\section{Cerabilia Castelnau, 1867}

Cerabilia Castelnau, 1867; type species, Cerabilia maori, Castelnau, F.L. Laporte de, 1867. = Zabronothus Broun 1893; type species, Zabronothus striatulus Broun, 1893.

= Nelidus Chaudoir, 1878; type species, Nelidus australis Chaudoir, 1878. syn. n.

= Australomasoreus Baehr, 2007; type species, Australomasoreus monteithi Baehr, 2007. syn. $\mathbf{n}$.

= Feronista Moore, 1965; type species, Feronista amaroides Moore, 1965. syn. n. 
Cerabilia australis (Chaudoir, 1878), comb. n.

= Nelidus australis Chaudoir, 1878

Material examined. Holotype, male [MNHN], type locality given as Paroo River area (QLD or NSW), but probably erroneous. See below.

Cerabilia monteithi (Baehr, 2007), comb. n.

= Australomasoreus monteithi Baehr, 2007

Material examined. Holotype, male [QM]. Type locality Bulburin State Forest via Many Peaks, Qld. An additional 12 specimens from the type locality [EMEC, QM].

Notes. Cerabilia, sensu Will (2011) includes Australian species placed in Feronista by Moore et al (1987) and Cerabilia species from New Zealand and New Caledonia. Baehr (2007) described Australomasoreus monteithi as a Masoreini, but he clearly noted that this placement was both anomalous for the species' characteristics and biogeography. Study of the type and additional material for both morphology and DNA data (Will unpubl.) clearly places this species in Cerabilia.

Cerabilia australis is known only from the holotype specimen and was reported as coming from the Paroo River area. However, this specimen is unlike any Australian species of carabid and is very similar to Cerabilia species from New Zealand. It may in fact be a synonym of one of the described New Zealand species, but until their types are studied this cannot be established. The Australian Cerabilia species are all restricted to the higher elevation rainforests in the northeastern coastal region. The Paroo River runs through the semi-arid inland region of southwestern Queensland and northwestern New South Wales and is both geographically and environmentally distant from any location where Cerabilia has been found in Australia. Likely the type locality was erroneously reported.

\section{Pterostichini Bonelli, 1810}

\section{= Cuneipectini Sloane, 1907. Syn. $n$.}

Cuneipectus Sloane, 1907; type species, Cuneipectus frenchi Sloane, 1907.

Material examined. Holotype, Cuneipectus frenchi [ANIC] and three additional specimens [ANIC, MCZ]; ten specimens of Cuniepectus foveatus Sloane, 1915 [EMEC].

Notes. Sloane described a new tribe for Cuneipectus suggesting that it belonged "at the beginning of the Trigonotomid series of the subfamily Harpalinae", i.e. as sister to a group Pterostichini. Subsequent authors have placed it between Harpalini and 
Chlaeniini (Csiki 1931), near chaetogenyines, chlaeniines, oodines, and licinines (Callistitae sensu Erwin and Sims (1984) and Erwin (1985, 1991)) in Licininae (Lorenz 2005) in Pterostichitae (Moore et al. 1987) or Pterostichini (Lawrence and Slipinski 2013). Moore (1965) did not include Cuneipectus in his treatment of Australian Pterostichinae. Aside from the original description, there has not been a discussion of the characteristics of Cuneipectus. Its variable placement, non-inclusion in Moore's (1965) treatment and frequent association with Chlaeniini and Licinini by various authors apparently stems from the species being described as having a single supraorbital setae in combination with the presence of an elytral plica. However, supraorbital seta number is variable, with some individuals having one and others two above each eye. Other characteristics are typical of Australian Pterostichini, including the presence of the spermathecal gland duct diverticulum (sgd) in the female (Liebherr and Will 1998). The sgd is typical in many pterostichines including Australian taxa like Prosopogmus Chaudoir, 1865 (Will 2011), Paranurus Tshitshérine, 1901 (Liebherr and Will 1998) and Trichosternus Chaudoir, 1865 (Will unpubl.). The sgd is not known to be present in any Chlaeniini or Licinini. Additionally, preliminary analyses of DNA data (Will unpubl.) consistently places Cuneipectus with Australian Pterostichini. Based on this evidence, Cuneipectus is placed in Pterostichini and Cuneipectini is synonymized.

\section{Oodini LaFerté-Sénectère, 1851}

Nanodiodes lilliputana (W.J. Macleay, 1888)

= Anatrichis lilliputana W.J. Macleay, 1888

Material Examined. Syntypes [ANIC], type locality, King Sound, Western Australia. Additional material in ANIC and WAM examined.

Notes. Nanodiodes Bousquet, 1996 was proposed by Bousquet (1996) to replace Nanodes Habu, 1956 and he moved all species that where included by Moore et al. (1987) in Anatrichus LeConte, 1853 into this genus except for Anatrichis lilliputana, which Bousquet had not studied. Although some subsequent catalogs (e.g., Lorenz 2005) treated this species as Nanodiodes lilliputana, there is no indication that the character states were confirmed. I examined the syntypes and found the following: submentum with pairs of setae at the lateral edge; mesocoxa with a posterior seta and; metatrochanter without a seta. This combination is consistent with Nanodiodes, confirming that it shares the putative synapomorphic character states with species currently included in that genus. Anatrichis is therefore not found in the Australian fauna.

\section{Acknowledgments}

I thank Cate Lemann, Australian National Insect Collection, CSIRO, who contributed significantly to this effort by seeking out, examining and imaging types and other 
material critical to this communication. I also thank Nadine Guthrie, Department of Parks and Wildlife, Western Australia for examining specimens of Oodini and Dr. Eva Sprecher-Uebersax of the Naturhistorisches Museum, Basel for taking and sending images of the type of Fouquetius variabilis. I thank Geoff Monteith, Queensland Museum for the extremely helpful suggestions and corrections in his review of the manuscript.

\section{References}

Baehr M (2007) A new genus of cyclosomine carabid beetles from Queensland, Australia (Insecta, Coleoptera, Carabidae, Cyclosominae). Mitteilungen Muenchener Entomologischen Gesellschaft 97: 5-9.

Bousquet Y (1996) Taxonomic Revision of Nearctic, Mexican, and West Indian Oodini (Coleoptera: Carabidae). The Canadian Entomologist 128: 443-537. doi: 10.4039/ Ent128443-3

Castelnau FLL de (1867) Notes on Australian Coleoptera. Transactions and Proceedings of the Royal Society of Victoria 8: 31-38.

Chaudoir M (1880) Essai monographique sur les Morionides. Bulletin de la Société Impériale des Naturalistes de Moscou 55(2): 317-384.

Csiki E (1931) Coleopterorum Catalogus 115 (Carabidae: Harpalinae V), 739-1022.

Erwin TL (1985) The taxon pulse: a general pattern of lineage radiation and extinction among carabid beetles. In: Ball GE (Ed.) Taxonomy, phylogeny and zoogeography of beetles and ants. A volume dedicated to the memory of Philip Jackson Darlington, Jr. (1904-1983). Series Entomologica, volume 33. Dr W. Junk Publishers, Dordrecht / Boston / Lancaster, 437-472.

Erwin TL (1991) The ground-beetles of Central America (Carabidae), part II: Notiophilini, Loricerini, and Carabini. Smithsonian Contributions to Zoology No. 501, 30 pp.

Erwin TL, Sims LL (1984) Carabid beetles of the West Indies (Insects: Coleoptera): a synopsis of the genera and checklists of tribes of Caraboidea, and of the West Indian species. Quaestiones Entomologicae 20: 351-466.

Lawrence J, Slipinski A (2013) Australian Beetles Volume 1, Morphology, Classification and Keys. CSIRO Publishing, 576 pp.

Liebherr JK, Will KW (1998) Inferring phylogenetic relationships within Carabidae (Insecta, Coleoptera) from characters of the female reproductive tract. In: Ball GE, Casale A, Taglianti AV (Eds) Phylogeny and Classification of Caraboidea Coleoptera: Adephaga). Proceedings of a Symposium (28 August, 1996, Florence, Italy). XX International Congress of Entomology. Atti Museo Regionale di Scienze Naturali di Torino, Italy, 107-170.

Lorenz W (2005) A Systematic List of Extant Ground Beetles of the World (Coleoptera "Geadephaga”: Trachypachidae and Carabidae, incl. Paussinae, Cicindelinae, Rhysodinae). 2nd ed. Tutzing.

Moore BP (1965) Studies on Australian Carabidae (Coleoptera) 4.-The Pterostichinae. Transactions of the Royal entomological Society of London 117: 1-32. doi: 10.1111/j.13652311.1965.tb00042.x 
Moore BP, Weir TA, Pyke JE (1987) Rhysodidae and Carabidae. In: Walton DW (Ed.) Zoological Catalogue of Australia, vol. 4 (Coleoptera: Archostemata, Myxophaga and Adephaga). Australian Government Publishing Service, Canberra, ACT, 20-230.

Sloane TG (1898) On Carabidae from west Australia, sent by Mr. A. M. Lea (with descriptions of new genera and species, synoptic tables, \&c.). Proceedings of the Linnean Society of New South Wales 23: 444-520.

Straneo SL (1941) Sui tipi dei Pterostichini (Coleopt. Carabid.) Australiani della collezione Castelnau nel Museo Civico di Genova Nota III. Annali Del Museo Civico Di Storia Naturale Giacomo Doria 61: 83-94.

Straneo SL (1960) Elenco di Carabidi entrati recentemente nelle collezioni del Museo Frey. Entomologische Arbeiten Munich 11: 416-428.

Will KW (2011) Taxonomic review of the Pterostichini and Loxandrini fauna of New Caledonia (Coleoptera, Carabidae). ZooKeys 147: 337-397. doi: 10.3897/zookeys.147.1943 